\title{
Arabic Error Analysis
}

\author{
Muhammad Yudo Agresi Akbari \\ Manajemen Pendidikan Islam \\ Universitas Muhammadiyah Sidoarjo \\ Sidoarjo, Indonesia
}

\begin{abstract}
This study aims to determine the Errors that often done by students in communicating with Arabic language and analyze it. This is especially important in Arabic Language Education, because a person's knowledge of language Errors and knowing the correction is very useful. The purpose of the correction is essentially so that everyone can stay away from it and not fall in the same mistake. Correction is the best way for Arabic speakers in the learning process. It is not only intended to know the speakers fault by simply noting their mistakes while speaking or writing, but rather towards improvement and effectiveness in the use of Language. The methods used in this study are tests, interviews and questionnaires. The results of this study indicate that the error is often done by the speaker is in the case idafah, al-shifat wa al-maushuf, al-fi'lu al-madhi, al-manshubat min al-af'al, with lam ta'lil, 'athf, tadhmir, tarkib al-jumlah, al-mustastnayat, al-asma' alkhamsah, al-ismu al-mamnu' min al-sharfi, kaana wa akhawatuha, ismu al-tafdhil, al-mubtada' wa al-khabar. the mistake is caused because of several things: 1). Weakness in understanding 2). Lack of practice especially in writing and insya', as for the solution on offer is 1). Using variations of teaching methods, 2) Streamlining assignments and evaluations, 3). Giving motivation to learn to improve activity in learning.
\end{abstract}

\section{Keywords—analysis; language errors; arabic}

\section{INTRODUCTION}

The study of fault analysis is a study related to the translation of the fault and its causes and to find a solution. As Stephen Peter Codder, the pioneer of the theory of fault analysis in the study of Language in the second half of the classical century, says: "The process of explaining the fault is itself a process of Language" [1].

This study becomes very important because the student's knowledge of the mistakes that occur in it will help to avoid such mistakes and try to justify them. This is also because the objective rather than the correction is essentially to show everyone to his mistake in order to away from it [2].And the correction of fault is a very helpful tool for someone in the teaching of a foreign language, So it is not only intended to know the fault but also to observe its mistakes when speaking or writing, which implies effectiveness in the use of Language [3].

This research writers do because of the emergence of various Errors in the language that is often done by the students in the campus STAI Ali bin Abi Thalib Surabaya which in fact apply an active Arabic boarding school. Therefore, the authors try to do research with the hope will be known to know the types of Errors that often occur, and not only that but can also find the cause of the Errors and can contribute positively to the development of Language on campus.

\section{RESEARCH METHODS}

Research method that writer use in conducting this research is qualitative method. In doing this research there are three techniques that are used in collecting data, that is as follows:

\section{A. Test}

The test is a collection of questions or exercises and in addition to what is used to know the ability or knowledge or mastery of a disciple in a science and especially in this case is the science of nahwu based on their answers [4].

In this test, the researcher asks the whole object of research to make the insya ' (essay) on a piece of paper that has been prepared by using Arabic.

\section{B.Questionnaire}

Questionnaire is one means of collecting data that is used in scientific research with a broad scope to obtain results of information or knowledge relating to the conditions, tendencies, views, impuses and beliefs of a person.[5].

This method is used to know the attitude of students to the course nahwu, the main problematics and methods of teaching teachers, including how to deal with the emergence of nahwu Errors that occurred in students

\section{Interview}

An interview is a dialogue between a researcher and a particular person to get the desired information from particular [6].And this method is also used to find out the problematic students in the course of nahwu and the cause of their mistakes,

In this technique the researchers come face to face with the respondent or the subject in detail. Researchers ask what has been planned to the respondent. The results are recorded as important information in the study.

\section{RESEARCH FINDINGS AND DISCUSSION}

This research is based on previous research, so researcher use two research below:

Fisrt, Research conducted by Muhammad Feryal Rahman, STAI Ali bin Abi Talib Surabaya Students. Year 
2012 with the thesis " Arabic Error Analysis " for 5th semester students at STAI Ali bin Abi Thalib Surabaya. And the conclusion of the study that language difficulties for students semester 5 about Errors in mudhaf mudhaf ilaih, al'adad wa al-ma'dud, al-shifat wa al-maushuf, al-athfu, aldhamair, al-mubtada' al-muakkhar, al-badal, kana wa akhawatuha, and inna wa akhawatuha.

Second. Research written by Siti Raudhatul Jannah, student UIN Sunan Ampel Surabaya in 2007 with the title Mistakes that often occur in the faculty of literature students. And the authors conclude that the Errors that often occur in the minutes of students of literature faculty at UIN Sunan Ampel Surabaya that is among the Errors of speech letters, in terms of style or in terms of dictionary, or in terms of structure, or in terms of tadzkir wa ta'nits, or ta'rif wa nakirah in a word or in terms of dhamair.

Make it easy to know the fault language with the explanation based on the standard of language rules learned. Because the language rules are part of the standard sciences that can avoid the pronunciation of Errors in expressing something and give directions to it when the fault occurs. Examples such as mantiq science that keeps a person in the mistake of thinking and morals that keep a person in a mistake behave.

\section{A. Teaching methods}

Below are the methods that are often and can be used in teaching Arabic language, among others:

\section{1) The classical method}

The classical method is one way of thinking that is in the sense to get from something in the know to the unknown [7].In this method, the teacher presents a rule to the student and then gives examples to practice it and the steps are as follows [8] :
a) Introduction,
b) Rule explanation,
c) Rule deepening and
d) Practice[9]

\section{2) Inductive method}

That is the method to draw conclusions, with the method the teacher starts by mentioning various examples and discuss it with the students then gradually conclude the rules and definitions with students, as for the steps - steps as follows:
a) Observing
b) Investigate with questions
c) Synthesize
d) Generalization and application

\section{3). Herbert's Method}

Herbert's method is the most suitable method of studying the rules. Which consists of five steps [10];
a)Introduction
b)Explanation
c)Synthesis
d) Connectivity with the previous rule
e) Generalization and application[11]

\section{4). Method of modification (literary text)}

The presentation of integrated text discussed by teachers with students to learn what is contained from grammatical phenomena through the system and its structure. The steps - steps are as follows:
a) Introduction
b) Explanation
c) Give examples of text
d) Concluding the rules
e) Application rules[12]

5) Active learning method

The method of active learning stands on its own accord that demands the exploitation of students effectiveness [13]Students are required to collect various styles of language, texts and examples containing the desired rules of practice, such as nawasikh, jar majrur, idhafah, adawat syrath, and from examples collected by each student to be the subject of discussion which ends with their conclusion of the desired rule [14].

\section{6) Problem solving method}

William Kalpatrick is the owner of this method, and he built this method based on Dewey's ideas related to experience and activities as a key element in the learning and teaching process [15.In this way students learn through their own activities and through their own experiences under the supervision of their teachers. And their activities are based on their interaction with their physical and social environment [16]

\section{7) Justification method (combination of active learning and problem solving method)}

This method is a combination of two methods that have been described earlier is the method of active learning and problem solving [17], this method is also a good way to teach the language rules for advanced students (higher education etc) and also beginners [18].

\section{B. Errors Factor}

Among the causes of Errors in the Arabic language both in terms of writing, reading and speaking, are as follows:

\section{1) Excessive in generalizing}

Joko defines generalization as "using the old strategy to modern views, in learning a second language, some of these strategies are useful in organizing facts about language, but on some others it may even be misleading and invalid"[19]. 


\section{2) Do not understand the language rules}

The incorrect generalization of the structure deals with the failure to understand the rules of structure, applying some rule to an inappropriate context, in which a student uses the rules he has used before and then applies in the new case. So it is possible for us to explain some of its Errors in terms of the rule through example or eg. And sometimes there are other cases that arise from a student just memorizing the rules alone without understanding the meaning [20].

\section{3) Less-rules Application}

We can observe the emergence of structures in which the distortion is contained within the level of development of a rule required to make a sentence acceptable. We can pay attention to systematic difficulties in the use of questions by speakers in different languages, they sometimes use news formats despite a lot of teaching questions and news formats. Because in fact the grammatical formulation of Arabic for questioning may not be part of a student's ability in a second language, and sometimes a movement can be an explanation for them [21].

\section{4) False assumption}

In addition to the various Errors in the language associated with learning that are in the question of rules based on different levels, there is a kind of evolutionary fault generated from a misconception with the basis of segregation in the target language, this is sometimes associated with the phases bad in teaching themes [22].

\section{B. Research findings:}

\section{1) Test}

From the previous explanation, we find that the type of mistake nahwu for students fourth semester about the fault in terms of use idhafah (merging words) (37\%), sifat wa almaushuf (adjectives ) (48,1 \%), fi'lu madhi (past verb) $(18,5 \%)$, lam ta'lil (letter to make the cause ) $(11 \%)$, athf (pronoun) (7,4\%), tadhmir (sentence structure) (11\%), mustatsnayat (exceptions) (3,7\%), al-asma al-khamsah (special nouns) (3,7\%), al-mamnu' min al-sharfi (verb (letters) $(7,3 \%)$, kaana wa akhawatuha (fixed noun) $((3,7 \%)$, an mudhmaroh (to declare more or more) $(7,4 \%)$, ismu tafdhil (4,7\%), al-mubtada' wa al-khabar (main sentence and explanation) $(3,7 \%)$.

\section{2) Questionnaire}

Analysis of the questionnaires conducted by researchers that most of their students liked the material. And sometimes it makes or motivates them in studying the course and also as we see that most students do not find the course difficult. And this reality sometimes also causes them to learn and focus on the course. Before entering the university. So their previous knowledge makes it easier to understand the course with a better understanding.
The other students who have difficulty in learning and understanding nahwu sometimes with the exercises that can help them. Because the practice makes them diligent in learning, reviewing and making them familiar in the study of scientific studies. Until they really understand. It is, however, deeply regretted that such exercises are only performed on a part-time basis, and among these tasks can show Errors of their answers. And most of them discuss the mistake with his lecturer. And this shows the positive attitude of the students towards the course in which they want to know the right answer until it is true and not to doing any more mistakes. And lecturers also always invite students to discuss and explain the mistakes that occurred With the students in the classroom. So, this activity makes the students become aware of the location of their mistakes and corrections at that time with good knowledge and perfect. So after the students know their mistake and the correction of most students justify the wrong answer on themselves. Then at the end of the session the lecturers provide motivation to the students to keep learning especially in chapter nahwu. Similarly, he ended his class together with his students by giving good advice and tausiyah related to motivation in learning.

\section{3) Interview}

The analysis of the interviews found that the students of $4^{\text {th }}$ semester generally have good attention and ability in learning nahwu knowledge in terms of comprehension and ability and lecturers are also very competent in teaching together with his students which he did not find any difficulty in the teaching process. Because he felt used to teaching since first. And many years. So his experience increased in the teaching of this course due to a very long experience.

The way in which lecturers in general are question and answer methods. After explaining the chapter in the study. Which lecturer asks a question to one of the students related to the course. Or, in answering practice. So if the lecturer finds his student wrong, in his speech or the answer, then he asks "why answer or read like this" until the student is able to know his own mistake, if he is not able then he asks the other students to the correct answer desired, if still no one can answer then the lecturer explained. So this method is his teaching method Because this method brings or shows students to know firsthand what is right. But, this activity is only done at the end of the session after an explanation that sometimes takes a long time in a very limited time.

\section{RESEARCH RESULT}

From the research that the writer did got findings findings as follows:

\section{A. Type of Error}

The types of Errors that are often done by students in the Arabic language, among others, in terms of use idhafah (merging words), sifat wa al-maushuf (adjectives ), fi'lu madhi (past verb), lam ta'lil (letter to make the cause ), athf 
(pronoun), tadhmir (sentence structure), mustatsnayat (exceptions), al-asma al-khamsah (special nouns), almamnu' min al-sharfi (verb (letters), kaana wa akhawatuha (fixed noun), an mudhmaroh (to declare more or more), ismu tafdhil, al-mubtada' wa al-khabar (main sentence and explanation).

\section{B. Causative factor}

From the research that the authors do then in know the factors - factors that affect Errors in Arabic by students STAI Ali bin Abi Thalib namely: 1) Weakness in understanding of structure, and 2) Lack of good and proper language practice.

\section{Impact.}

- The use of appropriate teaching methods for students especially those with a down - weak understanding

- Multiply the task / training at the end of each session

- Providing motivation, continuous advice to improve the quality of students.

\section{ACKNOWLEDGMENT}

I put on my greatest thanks to Universitas Muhammadiyah Sidoarjo for supporting this research.

\section{REFERENCES}

[1] JA. Jasem, NazariyatTahlil Al-Akhtha', al-Madinah al-munawwarah: --- pp. 151.

[2] M Yunus, Al-TarbiyahWa Al-Ta'lim Al-Juz Al-Taslits, Ponorogo: Dar Al-Salam, 2002, pp. 55.

[3] MK Al-Nakoh, Ta'lim Al-LughahAlarabiyyah, Makkah AkMukarramah, Jamiah Ummu Al-Qura, 1985, 263.

[4] SAraibij, Manahij Al-Bahtsi Al-Ilmi, Amman, Daru MajdiLawi, 1999,68

[5] S Araibij, Manahij Al-Bahtsi Al-Ilmi, Amman, Daru MajdiLawi, 1999, 68

[6] S Araibij, Manahij Al-Bahtsi Al-Ilmi, Amman, Daru MajdiLawi, 1999,155

[7] AM Madkur, TadrisFunun Al-Lughah Al-Arabiyyah, Cairo, Dar AlFikr Al-Islami, 2002, 298.

[8] M Yunus, Al-TarbiyahWa Al-Ta'lim Al-Juz Al-Taslits, Ponorogo: Dar Al-Salam, 2002, pp, 20

[9] B Syenin, ThuruqTadris Al-Lughah AlArabiyyahWaAlaqatuhaBifikrilbniKhaldun, Al-Jazair, MajallahAtsar, 2012, 118.

[10] MASaman, Al-Taujih Fi Tadris Al-Lughah Al-Arabiyyah, Cairo,Dar Al-Maarif, 1999, 19

[11] MA Saman, Al-Taujih Fi Tadris Al-Lughah Al-Arabiyyah, Cairo, Dar Al-Maarif, 1999, 151-152.

[12] MA Saman, Al-Taujih Fi Tadris Al-Lughah Al-Arabiyyah, Cairo, Dar Al-Maarif, 1999, 152-153.

[13] MSSamak, Fan Tadris Al-Lughah Al-Arabiyyah, Cairo, Dar Al-Fikri Al-Arabiy, 1998, 529.

[14] B Syenin, ThuruqTadris Al-Lughah AlArabiyyahWaAlaqatuhaBifikrilbni Khaldun, Al-Jazair, MajallahAtsar, 2012, 122.

[15] MS Samak, Fan Tadris Al-Lughah Al-Arabiyyah, Cairo, Dar AlFikri Al-Arabiy, 1998,529.
[16] SAMughalla, Al-Madkhol Ila Al-TarbiyahWa Al-Ta'lim, Amman, AlYazudi, 2002, 241.

[17] MA Saman, Al-Taujih Fi Tadris Al-Lughah Al-Arabiyyah, Cairo, Dar Al-Maarif, 1999, 154

[18] MI Shini, Al-Taqabul Al-LughawiWaTahlil Al-Akhtha', Riyadh, Mathabi' JamiahIbnuSuud, 1982, 121.

[19] MI Shini, Al-Taqabul Al-LughawiWaTahlil Al-Akhtha', Riyadh, Mathabi' JamiahIbnuSuud, 1982, 123.

[20] MI Shini, Al-Taqabul Al-LughawiWaTahlil Al-Akhtha', Riyadh, Mathabi' JamiahIbnuSuud, 1982, 124

[21] MI Shini, Al-Taqabul Al-LughawiWaTahlil Al-Akhtha', Riyadh, Mathabi' JamiahIbnuSuud, 1982, 125.

[22] AM Madkur, TadrisFunun Al-Lughah Al-Arabiyyah, Cairo, Dar AlFikr Al-Islami, 2002, 298 